\title{
PENGARUH KUALITAS JASA, HARGA, DAN FASILITAS TERHADAP KEPUASAN PELANGGAN PADA PT. JNE (Studi kasus pada PT. JNE Tomang 9 Jakarta Barat)
}

\author{
Anggi M Iqbal, Lucy Nancy *) \\ *Dosen Tetap FEB Universiats SatyaNegara Indonesia Jl.Arteri Pondok Indah No.11 Jakarta \\ E-mail: anggi12iqbal@gmail.com, lucynancysim@gmail.com
}

\begin{abstract}
ABSTRAK
Tujuan penelitian ini adalah untuk mengetahui pengaruh kualitas jasa, harga, dan fasilitas terhadap kepuasan pelanggan. Pupulasi pada penelitian ini seluruh pelanggan PT. JNE Tomang9, sedangkan sampel sebanyak 83 responden. Metode analisis data yang digunakan yaitu uji hipotesis (Uji F dan Uji t) dan Uji Analisis Regresi Linier Berganda. Hasil penelitian ini kualitas jasa dan harga berpengaruh terhadap kepuasan pelanggan, sedangkan fasilitas tidak berpengaruh terhadap kepuasan pelanggan.
\end{abstract}

\section{Kata Kunci: $\quad$ Kualitas Jasa, Harga, Fasilitas, Kepuasan Pelanggan}

\section{PENDAHULUAN}

Dalam kehidupan sehari-hari manusia bukan hanya membutuhkan makan dan minum saja, tetapi juga mempunyai kebutuhan atau keinginan yang lain. Seperti hal nya kebutuhan akan pengiriman barang dalam bidang jasa logistik, dimana pada saat ini perilaku pelanggan yang ingin serba cepat dan instan dalam menggunakan produk atau jasa demi memenuhi kebutuhannya untuk menjalani aktivitas di tengah kesibukan yang ada. Mengapa pelanggan harus menggunakan PT JNE, karena melihat akan hal ini PT. JNE khususnya di bidang jasa logistik pengiriman barang berupaya memudahkan pelanggan dalam menggunakan jasanya. Dalam menggunakan jasa PT. JNE, masyarakat tak perlu repot atau pergi dalam perjalanan jauh dan mengeluarkan banyak uang hanya untuk mengirimkan barang. Jadi masyarakat atau pelanggan hanya perlu mengantarkan barang ke agen atau outlet terdekat dengan biaya terjangkau di tambah dengan jaminan atau asuransi, sehingga dalam hal ini pelanggan bisa berhemat dalam segi waktu dan biaya.

Disamping itu era global sekarang ini, dalam dunia bisnis terjadi persaingan yang ketat, apalagi perusahaan dalam bidang jasa pengiriman barang logistik. Dimana pada era sekarang ini banyak pelanggan atau masyarakat yang gemar berbelanja melalui online shop yang proses pengiriman atau pengantarannya menggunakan jasa logistik. Jasa pengiriman barang yang sedang berkembang pesat dalam dua tahun terakhir ini sedang banyak di gunakan oleh pelanggan. Hadirnya jasa pengiriman barang ini sangat memudahkan pelanggan dalam kebutuhan sehari-hari maupun dalam kegiatan kerja. Hal ini juga membantu pelanggan yang mempunyai keterbatasan waktu dalam proses pengiriman barang.

Logistik yang berarti aliran barang atau jasa dari sumber barang atau pemasok ke tujuan atau penerima. Hal ini membuktikan bahwasanya dalam bisnis sangat membutuhkan jasa logistik atau pengiriman. Penyedia jasa logistik adalah komponen kedua yang menghubungkan produk dari hasil bisnis (pabrik) ke pelanggan ataupun reseller. Bukan hanya perusahaan besar atau pembisnis saja, bahkan dari kalangan perorangan banyak sudah menggunakan jasa tersebut.

Dalam mewujudkan kepuasan pelanggan tentunya pihak perusahaan logistik menggunakan harapan dan kebutuhan pelanggan sebagai patokan selama pemberian layanan. Kepuasan pelanggan dalam pelayanan pengiriman jasa logistik sangat penting untuk diperhatikan karena 
dapat menggambarkan kualitas pelayanan di tempat pelayanan pengiriman jasa tersebut. Di samping itu dengan mengetahui kepuasan pelanggan sangat bermanfaat bagi intansi terkait dalam rangka evaluasi program yang sedang di jalankan dan dapat menemukan bagian mana yang membutuhkan peningkatan.

Faktor-faktor yang mempengaruhi kepuasan pelanggan yaitu: Pertama Kualitas Jasa, pelanggan akan merasa puas bila mereka menunjukan bahwa produk atau jasa yang digunakan berkualitas, dimana pelanggan akan merasa puas jika mereka mendapat pelayanan yang baik dan sesuai dengan apa yang di harapkan. Kedua Harga, untuk pelanggan yang sensitive biasanya harga yang murah merupakan sumber kepuasan yang penting karna pelanggan akan mendapatkan value for money yang tinggi. Ketiga Emosional Faktor, pelanggan akan merasa puas karena adanya emosional value yang diberikan oleh brand dari produk tersebut. Keempat Biaya dan Kemudahan, pelanggan akan semakin puas apabila relatif mudah, nyaman dan efisien dalam mendapatkan produk atau pelayanan.

Kepuasan Pelanggan berkontribusi pada sejumlah aspek krusial, seperti terciptanya loyalitas pelanggan, dan meningkatnya reputasi perusahaan. Kepuasan Pelanggan merupakan hal yang sangat penting dalam menggunakan jasa atau produk, dimana pelanggan akan merespon kesesuaian dan ketidaksesuaian dengan apa yang sudah di rasakan oleh pelanggan.

Maka dari itu Kepuasan pelanggan sangat dipengaruhi oleh persepsi tentang Kualitas Jasa yang baik. Ini berarti semakin baik kualitas jasa berakibat pada semakin baiknya kepuasan pelanggan. Artinya apa yang di rasakan oleh pelanggan sesuai denga ekspetasi. Fenomena yang terjadi terkait Kualitas Jasa di PT. JNE Tomang 9 masih ada beberapa keterlambatan dalam proses pengiriman barang, dan di hari sabtu dan minggu sebagian outlet ataupun agen di daerah tertentu tidak bisa mengirimkan barangnya secara langsung, barang tersebut akan di proses saat hari senin, jadi dalam hal ini pelanggan harus menunggu lebih lama lagi dalam proses pengirimannya.

Dan juga jadwal kerja unit PT. JNE seperti agen, subagen, outlet, dll. Umumnya memiliki lebih dari satu di setiap wilayah. Bahkan, di beberapa daerah di satu atau dua kabupaten ada satu unit JNE. Meskipun dari Senin hingga Jumat, Anda dapat mengirim barang pada hari Sabtu atau Minggu. Namun barang mulai diproses pada hari Senin. Demikian juga, ketika Anda memesan suatu barang, jika barang itu tiba pada hari Sabtu di akhir jam kerja, barang itu akan dikirim pada hari Senin. Begitu juga pengiriman paket barang dan dokumen REG adalah layanan pengiriman untuk ke seluruh Indonesia dengan estimasi waktu sampai barang 1 hingga 7 hari kerja. Kecepatan pengiriman tergantung pada zona area pengiriman. Paket REG tidak dikirimkan pada hari Minggu dan hari libur nasional.

Harga merupakan label yang ada dalam sebuah produk yang harus dibayar agar bisa mendapatkan produk atau jasa. Harga juga menjadi suatu perbandingan dalam menggunakan produk atau jasa. Ini berarti jika harga yang di tentukan sesuai dengan apa yang di harapkan maka pelanggan akan merasa puas dalam menggunakan jasa tersebut.

Seperti hal nya harga dalam proses pengiriman pada PT. JNE dimana setiap perusahaan di bidang logistik atau pengiriman barang mempunyai harga yang bersaing misalnya perusahaan logistik seperti PT. JNE, J\&T Express, Sicepat. PT. J\&T Express mempunyai harga yang relative tinggi di banding dengan PT. JNE dan SiCepat. Tetapi yang sedang banyak di nikmati oleh pelanggan sekarang ini adalah J\&T Express di karnakan J\&T Express melakukan promosi dan cahs back (uang kembali) dan juga gratis ongkir (ongkos kirim) dalam pengiriman via online. Tetapi dalam hal tersebut brand rating PT. JNE masih berada di atas J\&T Express dan SiCepat dalam bidang pengiriman seperti tabel di bawah ini:

\section{Brand Rating - Logstics Sevice Industri.}




\begin{tabular}{|ll|c|}
\hline \multicolumn{1}{|c|}{ Brand } & Total Pelanggan \\
\hline 1. & Pos Indonesia & 3810 \\
\hline 2. & JNE & 3659 \\
\hline 3. & TIKI & 1646 \\
\hline 4. & ESL Express & 749 \\
\hline 5. & J\&T Express & 85 \\
\hline 6. & Wahana Prestasi Logistik & 39 \\
\hline 7. & Sicepat Express & 26 \\
\hline
\end{tabular}

Sumber: SWAonline.co.id

Tabel di atas merupakan urutan brand jasa logistik yang ada di Indonesia, jasa pengiriman barang atau jasa ekspedisi semakin hari semakin diminati oleh banyak masyarakat Indonesia, terutama dalam pasar online market.

Di Indonesia saja, terdapat beragam jasa pengiriman barang atau jasa ekspedisi yang memiliki kualitas mumpuni dengan pelayanan perima, sehingga banyak masyarakat yang memilihnya. Beragam pilihan ini juga memudahkan pengguna untuk menentukan jasa ekspedisi yang sesuai dengan kebutuhan, segi harga, kecepatan pengiriman, kemudahan maupun faktor lainnya.

Fasilitas akan menunjang perusahaan sehingga lebih bermutu dan berkualitas, dengan itu kepuasan pelanggan akan tercipta. Fasilitas merupakan segala sesuatu yang mempermudah pelanggan dalam memperoleh manfaat dari jasa yang di berikan. Fasilitas merupakan sarana maupun prasarana yang penting dalam usaha meningkatkan kepuasan seperti memberi kemudahan, memenuhi kebutuhan dan kenyamanan bagi pengguna jasa. Apabila fasilitas yang disediakan sesuai dengan kebutuhan, maka pelanggan akan merasa puas. Fenomena yang terjadi terkait Fasilitas di PT. JNE Tomang 9 yaitu tempat parkir atau tata letak kendaraan yang kurang luas sehingga masih ada beberapa kendaraan yang harus memakirkan kendaraanya di atas trotoar. Sehingga masih banyak pelanggan atau karyawan yang kesulitan dalam memakirkan kendaraannya hal itu menjadi masalah bagi perusahaan. Karna fasilitas merupakan salah faktor penting untuk memuaskan pelanggan dengan fasilitas yang di berikan sehingga pelanggan merasa puas merasa nyaman dan mendapatkan nilai lebih ketika menggunakan produk atau jasa tersebut.

Berdasarkan fenomena masalah dan adanya perbedaan hasil penelitian, maka peneliti bermaksud untuk melakukan penelitian dengan judul "PENGARUH KUALITAS JASA, HARGA, DAN FASILITAS TERHADAP KEPUASAN PELANGGAN PADA PT. JNE" (Studi kasus pada PT. JNE di Jalan Tomang Raya No. 9)

\section{TINJAUAN PUSTAKA}

\section{Kepuasan Pelanggan}

Menurut Fandy Tjiptono (2017:358) mengungkapan bahwa "Kepuasan pelanggan adalah situasi kognitif pembeli berkenaan dengan kesepadanan atau ketidaksepadanan antara hasil yang didapatkan dibandingkan dengan pengorbanan yang dilakukan"

Dimensi dan Indikator Kepuasan Pelanggan adalah sebagai berikut:

Menurut Fandy Tjiptono (2015:368) terdapat tiga dimensi utama yang disusun sesuai urutan tingkat kepentingan dalam kepuasan pelanggan sebagai berikut :

1. Konfirmasi Harapan (Confirmation Of Expectation, dengan indikator:

a. Keinginan Pelanggan, merupakan suatu keinginan pelanggan dimana perusahaan bisa mewujudkan keinginan tersebut. Dimana hal tersebut bisa menjadi suatu hal yang 
positif bagi perusahaan, sehingga dalam hal ini perusahaan bisa menjaga kelngsungan hidup karyawan dan perusahaanya.

b. Kinerja, merupakan tingkat keberhasilan seseorang dalam menjalankan suatu tugas.

2. Minat Beli Ulang (Repurchase Intention)

Kepuasan pelanggan diukur secara behavioral dengan jalan menanyakan apakah pelanggan akan berbelanja atau menggunakan jasa perusahaan lagi. Indikator mengenai dimensi tersebut adalah Pemakaian ulang merupakan pemakaian yang berulang kali yang dilakukan oleh konsumen atau pelanggan dimana dalam pemakain tersebut.

3. Ketersedian Untuk Merekomendasi (Willingness to Recommend) dengan indikator:

a. Menyarankan Orang Lain dimana pelanggan yang sudah mengunakan produk atau jasa tersebut menyarankan kepada orang lain yang belum menggunakan produk atau jasa tersebut.

b. Media Sosial membagikan pengalamannya ketika menggunakan produk atau jasa tersebut ke media sosial.

\section{Kualitas Jasa}

Menurut Kotler dan Keller (2016:36) Kualitas Jasa didefinisikan sebagai "setiap tindakan atau perbuatan yang dapat ditawarkan oleh suatu pihak kepada pihak lain yang pada dasarnya bersifat intangible (tidak berwujud fisik) dan tidak menghasilkan kepemilikan sesuatu". Dimensi dan Indikator Kualitas Jasa adalah sebagai berikut:

Menurut Fandy Tjiptono (2017:134) ada lima dimensi kualitas jasa yaitu :

a. Bukti Fisik (Tangibles) dengan indikator:

1. Pegawai, merupakan seseorang yang bekerja dalam suatu perusahaan dimana pegawai tersebut menggunakan atribut perusahaan. Seperti, seragam, tanda pengenal dan lain-lain.

2. Peralatan, dimana perusahaan menyediakan alat yang mendukung proses pekerjaan untuk memudahkan pegawai dalam proses pelayanan.

3. Fasilitas fisik, menyediakan sarana dan prasarana untuk kenyamanan konsumen atau pelanggan.

b. Keandalan (Reliability), dengan indikator:

1. Layanan yang di janjikan, dimana dalam hal pelayanan sesuai dengan ketentuan.

2. Layanan yang memuaskan, memberikan layanan yang baik dimana pelayanan tersebut sesuai dengan prosedur yang ada.

3. Layanan akurat, layanan sesuai dengan apa yang di tuju oleh konsumen atau pelanggan.

c. Daya Tanggap (Responsiveness) dengan indikator:

1. Membantu pelanggan, karyawan atau pegawai membantu pelanggan pada proses pelayanan dalam menggunakan produk atau jasa.

2. Layanan tanggap, karyawan atau pegawai tanggap dalam menangani keluhan atau masalah yang di hadapi konsumen atau pelanggan.

3. Profesional, Karyawan atau pegawai memiliki ke ahlian akan pekerjaan tersebut.

d. Jaminan (Assurance), dengan indikator sebagai berikut:

1. Pengetahuan, karyawan atau pegawai memliki pengetahuan luas dalam proses pelayanan.

2. Kesopanan, karyawan atau pegawai memiliki etika yang baik dalam memperlakukan konsumen atau pelanggan.

3. Bebas dari bahaya, dimana perusahaan bertanggung jawab terhadap kerusakan, kehilangan dalam proses pengiriman suatu barang.

e. Empati (Empathy), dengan indikator sebagai: 
1. Komunikasi baik, karyawan atau pegawai memiliki komunikasi yang baik antar pegawai dan pelanggan.

2. Perhatian pribadi, memberikan perhatian secara personal atau khusus terhadap konsumen atau pelanggan.

3. Pemahaman kebutuhan, karyawan atau pegawai mengetahui apa yang di butuhkan oleh konsumen atau pelanggan.

\section{Harga}

Menurut Kotler dan Keller (2016:68) "Harga adalah sejumlah uang yang dibebankan atas suatu produk atau jasa, atau jumlah dari nilai uang ditukar konsumen atas manfaat karena memiliki atau menggunakan produk atas jasa tersebut”.

Dimensi dan Indikator Harga adalah sebagai berikut:

Menurut Kotler (2016:91) dimensi harga meliputi:

a. Daftar Harga, berkaitan dengan kemampuan perusahaan untuk memberikan harga dari masing-masing produk atau jasa yang ingin di gunakan sesuai dengan manfaat yang di peroleh pelanggan. Dengan indikator sebagai berikut:

1. Harga sesuai jasa, dimana harga yang di berikan perusahaan sesuai dengan apa yang di harapkan pelanggan.

2. Keterjangkauan harga, dalam hal ini perusahaan memberi harga yang terjangkau (murah) kepada pelanggan.

3. Daya saing harga, dalam hal ini harga yang di tentukan bersaing dengan harga dari competitor lain.

b. Potongan Harga, berkaitan dengan kemampuan perusahaan untuk memberikan potongan harga kepada pelanggan. Misalkan potongan harga pada hari tertentu atau event yang di lakukan oleh perusahaan. Dengan indikator sebagai berikut:

1. Potongan harga di hari tertentu, misalhanya mendapatkan potongan pada hari besar tertentu, misalkan seperti hari raya, ulang tahun perusahaan dan sebagainya.

2. Potongan lewat aplikasi, ketika berbelanja lewat aplikasi atau online shop akan mendapatkan potongan harga seperti gratis ongkos kirim.

\section{Fasilitas}

Menurut Fandy Tjiptono (2017:192) “Harga merupakan satu-satunya unsur bauran pemasaran yang memberikan pemasukan atau pendapatan bagi perusahaan dalam menghasilkan laba."

Dimensi dan Indikator Fasilitas adalah sebagai berikut:

Menurut Fandy Tjiptono (2016:96) dimensi dan indikator ialah sebagai berikut:

1. Perencanaan Spasial

Perancangan untuk menciptakan lingkungan tertentu yang mampu mendorong terbentukanya respon pelanggan sebagaimana dikehendaki penyedia jasa. Dengan indikator sebagai berikut:

a. Warna, dalam perusahaan pasti memiliki ruangan-ruangan tertentu dengan corak warna yang mempunyai arti dan menyesuaikan dengan ruangan tersebut.

b. Simetri, karakteristik yang terdapat dalam suatu bangunan dimana bangunan tersebut menggambarkan rasa emosional.

2. Perencanaan Ruangan

Eksperesi yang mencerminkan lingkup hidup kebijakan yang dibuat dalam perusahaan terkait dengan sosial, dan kebudayaan mereka. Dengan indikator sebagai berikut:

a. Interior, proses merancang dalam ruangan, yang biasanya meliputi luar ruangan dari sebuah ruangan atau bangunan. 
b. Arsitektur, perencanaan dan perancangan lingkungan dari suatu perusahaan terhadap perancangan bangunan.

c. Sirkulasi, proses pergantian udara dalam ruangan dalam hal ini perusahaan harus memiliki sirkulasi udara yang baik.

3. Perlengkapan

Perlengkapan atau perabotan memiliki beberapa fungsi, di antaranya sebagai sarana pelindung barang-barang berharga berukuran kecil, sebagai barang pajangan, sebagai tanda penyambutan bagi para pelanggan, dan sebagai sesuatu yang menunjukkan status pemilik atau penggunanya. Dengan indikator sebagai berikut:

a. Pelindung barang berharga, dalam menjalankan tugas perusahaan harus memiliki peralatan fasilitas untuk melindungi barang berharga yang di miliki perusahaan.

b. Barang pajangan, bukan hanya desain interior saja tetapi perusahaan juga biasanya menaruh barang pajangan di suatu ruangan atau tempat tertentu yang tujuannya memperindah suasana dimana mempunyai kesan tersendiri di mata pelanggan.

4. Tata Cahaya

Pengaturan cahaya dengan mempergunakan peralatan pencahayaan dimana pelanggan mendapatkan kesan adanya jarak, ruang, waktu dan suasana yang di berikan oleh perusahaan. Dengan indikator sebagai berikut:

a. Tata cahaya siang hari, dimana pencahayaan di siang hari harus jelas guna mempermudah kerja karyawan dalam melayani pelanggan, disamping itu juga pelanggan merasa nyaman akan pencahayaan yang ada.

b. Suasana yang di inginkan, dalam hal ini suasana yang dilakukan perusahaan harus tertata dengan rapih, bersih, dan beraturan.

\section{METODOLOGI PENELITIAN}

\section{Waktu dan Tempat Penelitian}

Penelitian ini dilakukan di Universitas Satya Negara Indonesia kampus A. Penelitian dilakukan mulai dari bulan Agustus 2019 s/d Januari 2020.

\section{Desain Penelitian}

Jenis penelitian ini adalah penelitian kausal yaitu penelitian untuk mengetahui pengaruh satu atau lebih variabel bebas (independent variable) terhadap variabel terikat (dependent variable)

\section{Metode Pengumpulan Data}

teknik pengumpulan data yang dipergunakan dalam penelitian ini adalah sebagai berikut:

a. Studi Kepustakaan

b. Metode Kuisioner

c. Observasi

\section{Populasi dan Sampel}

Populasi ini dilakukan pada seluruh pelanggan PT. JNE Tomang 9. Dalam penelitian ini menggunakan rumus Roscoe dengan penetapan sampel yang digunakan yaitu:

$\mathrm{n}=(10) \times 4=40$

Keterangan:

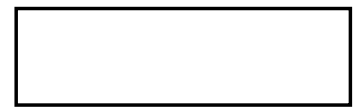

$$
\mathrm{n}=10 \times \mathrm{K}
$$


$\mathrm{n}=$ Responden

$\mathrm{k}=$ variable penelitian yang digunakan

$10=$ jumlah observer menurut Roscoe

Pada penulisan ini sampel yang digunakan dalam penelitian ini ialah sebanyak 83 responden.

\section{ANALISIS HASIL DAN PEMBAHASAN}

\section{Uji Hipotesis}

Uji F

Uji $F$ menunjukkan semua variabel independen mempunyai pengaruh secara bersamasama terhadap variabel dependen. Kriteria pengujian keputusannya dengan tingkat signifikansi (a) $=0,05$ adalah dengan membandingkan nilai $F$ hitung dengan $F$ tabel yaitu:

a. Jika $\mathrm{F}$ hitung $>\mathrm{F}$ tabel maka, Ho ditolak dan Ha diterima

b. Jika $\mathrm{F}$ hitung $<\mathrm{F}$ tabel maka, Ho diterima dan Ha ditolak

Berdasarkan signifikansi

a. Jika signifikansi $>0,05$ maka, Ho diterima dan Ha ditolak

b. Jika signifikansi $<0,05$ maka, Ho ditolak dan Ha diterima

Menentukan $\mathrm{f}$ tabel pada tingkat signifikansi 0,05 dengan df 1 (jumlah variabel - 1) atau 4-1 = 3, dan df2 (n-k-1) atau 83-3-1 = 67, maka hasil $\mathbf{F}$ tabel $=\mathbf{2 , 7 2 0}$.

Hasil Uji F

ANOVA $^{\mathrm{a}}$

\begin{tabular}{|ll|r|r|r|r|r|}
\hline Model & & Sum of Squares & \multicolumn{1}{|c|}{ Df } & Mean Square & F & \multicolumn{1}{c|}{ Sig. } \\
\hline 1 & Regression & 613.382 & 3 & 204.461 & 14.272 & $.000^{\mathrm{b}}$ \\
& Residual & 1131.775 & 79 & 14.326 & & \\
& Total & 1745.157 & 82 & & & \\
\hline
\end{tabular}

a. Dependent Variable: Kepuasan Pelanggan

b. Predictors: (Constant), Fasllitas, Kualitas Jasa, Harga

Sumber: Output SPSS Ver.22, 2020

Pada tabel 4.18 menunjukkan hasil uji $\mathrm{F}$ dengan nilai sebesar 14,272 $>\mathbf{2 . 7 2 0}$ dan nilai signifikansi sebesar $0,000<005$ maka Ho ditolak. Yang artinya variabel independen (Kualiatas Jasa, Harga, dan Fasilitas) secara simultan berpengaruh positif dan signifikan terhadap variabel dependen (Kepuasan Pelanggan).

\section{Uji t}

Uji t pada dasarnya menunjukkan seberapa jauh pengaruh variabel independen secara individual terhadap variabel dependen. Cara melakukan uji t dengan tingkat signifikansi (a) $=0,05$ adalah dengan membandingkan nilai thitungnya dengan $\mathrm{t}$ tabel yaitu:

a. Jika t hitung $>\mathrm{t}$ tabel maka, Ho ditolak dan Ha diterima

b. Jika t hitung $<\mathrm{t}$ tabel maka, Ho diterima dan Ha ditolak

Berdasarkan signifikansi:

a. Jika signifikan $>0,05$ maka Ho diterima dan Ha ditolak

b. Jika signifikan $<0,05$ maka Ho ditolak dan Ha diterima

Menentukan $t$ tabel dapat dilihat pada $t$ tabel signifikansi 0,05 dengan derajat kebebasan $\mathrm{df}=\mathrm{n}-\mathrm{k}-1$ atau 83-3-1=79 adalah jumlah responden, maka didapat nilai $\mathbf{t}$ tabel $=\mathbf{1 , 9 9 0}$

Hasil Uji T

Coefficients $^{\mathrm{a}}$

\begin{tabular}{|l|c|c|c|c|c|c|}
\hline \multirow{2}{*}{ Model } & \multicolumn{2}{|c|}{$\begin{array}{c}\text { Unstandardized } \\
\text { Coefficients }\end{array}$} & $\begin{array}{c}\text { Standardized } \\
\text { Coefficients }\end{array}$ & \multirow{2}{*}{$\mathrm{t}$} & Sig. & \multicolumn{2}{|c|}{$\begin{array}{c}\text { Collinearity } \\
\text { Statistics }\end{array}$} \\
\cline { 2 - 6 } & B & Std. Error & Beta & Tolerance & VIF \\
\hline
\end{tabular}




\begin{tabular}{|ll|r|r|r|r|r|r|r|}
\hline 1 & (Constant) & 7.637 & 6.433 & & 1.187 & .239 & & \\
& .182 & .063 & .316 & 2.915 & .005 & .698 & 1.434 \\
& Kualitas Jasa & .261 & .124 & .230 & 2.113 & .038 & .691 & 1.447 \\
Harga & .087 & .055 & .181 & 1.579 & .118 & .623 & 1.604 \\
\hline
\end{tabular}

a. Dependent Variable: Kepuasan Pelanggan

Sumber: Output SPSS Ver.22, 2020

Hasil uji t dari 4.19 dijelaskan sebagai berikut:

a. Variabel Kualitas Jasa (X1) nilai t hitung $>t$ tabel $(2,915>1,990)$ dan nilai signifikansi $(0,005<0,05)$ maka Ho ditolak, yang artinya Kualitas Jasa berpengaruh signifikan terhadap Kepuasan Pelanggan.

b. Variabel Harga $(\mathrm{X} 2)$ nilai $t$ hitung $>\mathrm{t}$ tabel $(2,113>1,990)$ dan nilai signifikansi $(0,038<$ 0,05) maka Ho ditolak, yang artinya Harga berpengaruh signifikan terhadap Kepuasan Pelanggan.

c. Variabel Fasilitas (X3) nilai t hitung $<\mathrm{t}$ tabel $(1,579<1,990)$ dan nilai signifikansi $(0,118<$ 0,05) maka Ho diterima, yang artinya Fasilitas tidak berpengaruh signifikan terhadap Kepuasan Pelanggan.

\section{Uji Regresi Linier Berganda}

Analisis Regresi Linier Berganda digunakan untuk menganalisis Pengaruh Kualitas Jasa (X1), Harga (X2), dan Fasilitas (X3) terhadap Kepuasan Pelanggan (Y).

\section{Hasil Uji Regresi Linier Berganda}

\begin{tabular}{|c|c|c|c|c|c|c|c|c|}
\hline \multicolumn{9}{|c|}{ Coefficients $^{\mathrm{a}}$} \\
\hline \multirow{2}{*}{\multicolumn{2}{|c|}{ Model }} & \multicolumn{2}{|c|}{$\begin{array}{c}\text { Unstandardized } \\
\text { Coefficients }\end{array}$} & \multirow{2}{*}{$\begin{array}{c}\text { Standardized } \\
\text { Coefficients }\end{array}$} & \multirow[b]{2}{*}{$\mathrm{t}$} & \multirow[b]{2}{*}{ Sig. } & \multicolumn{2}{|c|}{$\begin{array}{c}\text { Collinearity } \\
\text { Statistics }\end{array}$} \\
\hline & & $\mathrm{B}$ & Std. Error & & & & Tolerance & VIF \\
\hline 1 & (Constant) & 7.637 & 6.433 & & 1.187 & .239 & & \\
\hline & Kualitas Jasa & .182 & .063 & .316 & 2.915 & .005 & .698 & 1.434 \\
\hline & Harga & .261 & .124 & .230 & 2.113 & .038 & .691 & 1.447 \\
\hline & Fasllitas & .087 & .055 & .181 & 1.579 & .118 & .623 & 1.604 \\
\hline
\end{tabular}

a. Dependent Variable: Kepuasan Pelanggan

Sumber: Output SPSS Ver.22, 2020

Tabel 4.14 menunjukkan hasil uji regresi linier berganda, dapat diperoleh persamaan regresi sebagai berikut:

$\mathrm{Y}=7,637+0,182 \mathrm{X}_{1}+0,261 \mathrm{X}_{2}+0,087 \mathrm{X}_{3}$

Dari hasil analisis dan persamaan regresi linier berganda tersebut dapat diambil kesimpulan sebagai berikut:

a. Nilai Konstanta adalah 7,637 yang artinya jika Kualitas Jasa, Harga, dan Fasilitas terhadap Kepuasan Pelanggan nilainya 0, maka Kepuasan Pelanggan akan bernilai sebesar 7,673.

b. Koefisien Regresi Kualitas Jasa (X1) bersifat positif sebesar 0,182 yang artinya jika variabel Kualitas Jasa meningkat 1 satuan, maka akan meningkatkan Kepuasan Pelanggan sebesar 0,182 dengan asumsi variabel lain tetap.

c. Koefisien Regresi Harga (X2) bersifat positif sebesar 0,261 yang artinya jika variabel Harga meningkat 1 satuan, maka akan meningkatkan Kepuasan Pelanggan sebesar 0,261 dengan asumsi variabel lain tetap.

d. Koefisien Regresi Fasilitas (X3) bersifat positif sebesar 0,087 yang arinya jika variabel Fasilitas meningkat 1 satuan, maka akan meningkatkan Kepuasan Pelanggan sebesar 0,087 dengan asumsi variabel lain tetap. 


\section{KESIMPULAN DAN SARAN}

\section{Kesimpulan}

Berdasarkan hasil penelitian ini bertujuan untuk menguji pengaruh dari variable Kualitas Jasa, Harga, dan Fasilitas terhadap Kepuasan Pelanggan pada PT. JNE Tomang 9. Kesimpulan dari peneliti ini adalah:

1. Variabel Kualitas Jasa (X1), Harga (X2) dan Fasilitas (X3) secara simultan berpengaruh signifikan terhadap Kepuasan Pelanggan (Y) di PT. JNE Tomang 9.

2. Variabel Kualitas (X1) secara parsial berpengaruh signifikan terhadap Kepuasan Pelanggan (Y) di PT. JNE Toamang 9.

3. Variabel Harga (X2) secara parsial berpengaruh signifikan tehadap Kepuasan Pelanggan (Y) di PT. JNE Tomang 9.

4. Variabel Fasilitas (X3) secara parsial tidak berpengaruh dan tidak signifikan terhadap Kepuasan Pelanggan (Y) di PT. JNE Toamng 9.

\section{Saran}

Berdasarkan penelitian ini, peneliti perlu memberi saran yang mungkin dapat dipertimbangkan oleh PT. JNE Tomang 9. Adapun saran-saran yang dapat diberikan sebagai berikut:

1. Berdasarkan indikator dengan skor terendah pada variabel Kualitas Jasa yaitu karyawan memiliki tubuh yang proporsional (ideal), dalam hal ini responden atau pelanggan tidak terlalu mempermasalahkan hal tersebut, melainkan pelanggan lebih mengharapkan dengan proses pengiriman yang cepat dan akurat.

2. Berdasarkan indikator dengan skor terendah pada variable Harga yaitu mendapatkan potongan harga dalam jumlah banyak. Dalam hal ini akan lebih baik jika PT. JNE Tomang 9 memberikan potongan harga kepada pelanggan yang mengirimkan dengan jumlah yang banyak, karna dari potongan tersebut bisa menarik pelanggan dalam pengiriman barang, yang dimana belum terdapat pada kompititornya.

3. Fasilitas menjadi satu-satunya variabel yang tidak berpengaruh signifikan terhadap Kepuasan Pelanggan. Semakin lengkap fasilitas yang di berikan maka akan semakin tinggi juga tingkat Kepuasan Pelanggan yang di peroleh pelanggan. Maka PT. JNE Tomang 9 disarankan untuk lebih meningkatkan fasilitas yang menambah kepuasan pelanggan.

\section{DAFTAR PUSTAKA}

\section{Sumber Buku:}

Anang Firmansyah \& Didin Fatihudin. Pemasaran Jasa (Strategi Mengukur kepuasan dan Loyalitas Pelanggan) 2019.

Fandy Tjiptono, Pemasaran Jasa-Prinsip Penerepan, dan Penelitian 2017.

Fandy Fandy Tjiptono \& Gregorius Chandra Service, Quality \& Satisfaction Edisi 42016.

Philip Kotler \& Kevin Lane Keller 2016 Edisi: 13 Jilid I.

Priyatno, Duwi. 2017. SPSS22 Pengolah Data Terpraktis. Andi. Yogyakarta

Rambat Lupiyoadi. 2016. Manajemen Pemasaran Jasa: Berbasis Kompetensi. Salameba Empat.

Sugiyono. 2016. Metode Penelitian Kuantitatif, Kualitatif dan R\&D Bandung: PT. Alfabet.

\section{Sumber Jurnal:}

Ana Fitriyatul Bilgies: Peran Kualitas Produk, Harga, dan Kualitas Jasa terhadap Kepuasan Pelanggan Billagio Skincare Clinic Sidoarjo, 2016.

Dealisna Pantilu, Rosalina A.M Ferdy Roring: Pengaruh Kualitas Jasa, Harga, dan Fasilitas terhadap Kepuasan Pelanggan Pada Warung Bendito Manado, 2018.

Didik Nurdiansyah dan Dian Ayu Liana Dewi: Pengaruh Citra, Kualitas Pelayanan, dan Fasilitas terhadap Kepuasan Pelanggan pada Primaga cabang Rembang, 2018. 
Fanly W Manus, Bode Lumanauw: Pengaruh Kualitas Produk, Harga, dan Kualitas Jasa terhadap Kepuasan Pelanggan pada Kartu Prabayar Tri di Tondono Barat, 2015.

Mia Audina dan Sri Langgeng Ratnasari: Pengaruh Fasilitas, Harga, dan Citra Perusahaan terhadap Kepuasan Pelanggan di Hotel Hana Batam, 2017.

Rochyan Ridho, Mukeri Warso, Aziz Fathoni: Pengaruh Kualitas jasa Terhadap Kepuasan Pelanggan pada PT. Graha Service Indonesia cabang Semarang. 2016. 